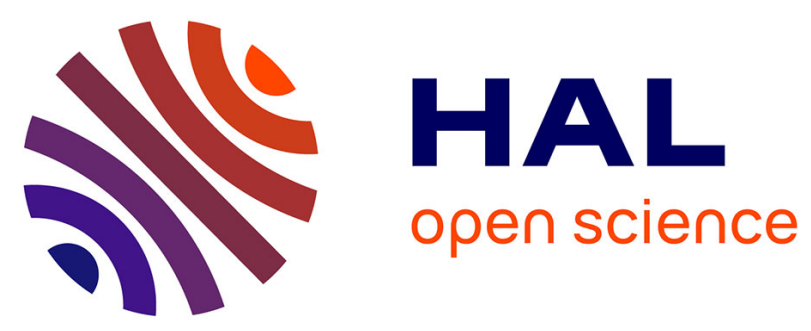

\title{
Molecular basis of resistance to macrolides; lincosamides and streptogramins in clinical isolates
}

\author{
Anne Le Bouter, Roland Leclercq, Vincent Cattoir
}

\section{To cite this version:}

Anne Le Bouter, Roland Leclercq, Vincent Cattoir. Molecular basis of resistance to macrolides; lincosamides and streptogramins in clinical isolates. International Journal of Antimicrobial Agents, 2011, 37 (2), pp.118. 10.1016/j.ijantimicag.2010.10.008 . hal-00659903

\section{HAL Id: hal-00659903 https://hal.science/hal-00659903}

Submitted on 14 Jan 2012

HAL is a multi-disciplinary open access archive for the deposit and dissemination of scientific research documents, whether they are published or not. The documents may come from teaching and research institutions in France or abroad, or from public or private research centers.
L'archive ouverte pluridisciplinaire HAL, est destinée au dépôt et à la diffusion de documents scientifiques de niveau recherche, publiés ou non, émanant des établissements d'enseignement et de recherche français ou étrangers, des laboratoires publics ou privés. 


\section{Accepted Manuscript}

Title: Molecular basis of resistance to macrolides; lincosamides and streptogramins in Staphylococcus saprophyticus clinical isolates

Authors: Anne Le Bouter, Roland Leclercq, Vincent Cattoir

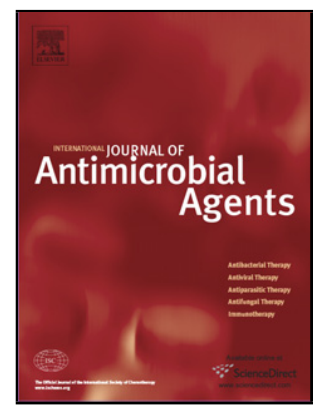

PII:

S0924-8579(10)00455-3

DOI: doi:10.1016/j.ijantimicag.2010.10.008

Reference: ANTAGE 3448

To appear in: International Journal of Antimicrobial Agents

Received date: $\quad 3-8-2010$

Revised date: $\quad 17-9-2010$

Accepted date: $\quad 2-10-2010$

Please cite this article as: Le Bouter A, Leclercq R, Cattoir V, Molecular basis of resistance to macrolides; lincosamides and streptogramins in Staphylococcus saprophyticus clinical isolates, International Journal of Antimicrobial Agents (2010), doi:10.1016/j.ijantimicag.2010.10.008

This is a PDF file of an unedited manuscript that has been accepted for publication. As a service to our customers we are providing this early version of the manuscript. The manuscript will undergo copyediting, typesetting, and review of the resulting proof before it is published in its final form. Please note that during the production process errors may be discovered which could affect the content, and all legal disclaimers that apply to the journal pertain. 


\section{Molecular basis of resistance to macrolides, lincosamides and streptogramins in Staphylococcus saprophyticus clinical isolates}

Anne Le Bouter, Roland Leclercq, Vincent Cattoir *

Service de Microbiologie, CHU Côte de Nacre, and Équipe EA 2128 'Interactions Hôtes

et Microorganismes des Épithéliums', Faculté de Médecine de Caen, Université Caen

Basse-Normandie, 14033 Caen, France

ARTICLE INFO

Article history:

Received 3 August 2010

Accepted 2 October 2010

Keywords:

MLS resistance

Coagulase-negative staphylococci

CoNS

$m s r(\mathrm{~A})$

$\operatorname{erm}(\mathrm{C})$

$\ln u(A)$ 
${ }^{*}$ Corresponding author. Present address: Service de Microbiologie, CHU Côte de

Nacre, Avenue Côte de Nacre, 14033 Caen cedex, France. Tel.: +33 2310645 72; fax: +33231064573.

E-mail address: cattoir-v@chu-caen.fr (V. Cattoir). 


\section{ABSTRACT}

The aim of this study was to evaluate the prevalence of resistance to macrolidelincosamide-streptogramin (MLS) antibiotics as well as to assess the molecular basis of this resistance among 72 Staphylococcus saprophyticus urinary isolates collected from 2005 to 2009 in University Hospital of Caen (France). Of the 72 strains studied, 33 (45.8\%) were resistant to at least one MLS antibiotic, including $24(72.7 \%)$ with an M phenotype, 5 (15.2\%) with an inducible $\mathrm{MLS}_{\mathrm{B}}$ phenotype, $3(9.1 \%)$ with a combined $M+L$ phenotype and $1(3.0 \%)$ with an $L$ phenotype. All isolates were susceptible to the combination of streptogramins $A$ and $B$. The resistance genes $\operatorname{erm}(A) \operatorname{erm}(B), \operatorname{erm}(C)$, $m s r(\mathrm{~A})$ and $\ln u(\mathrm{~A})$ were detected alone in 0, 0, $5(15.2 \%), 24(72.7 \%)$ and $1(3.0 \%)$ of the 33 MLS-resistant isolates, respectively, whereas 2 strains (6.1\%) were positive for both $\operatorname{msr}(\mathrm{A})$ and $\operatorname{lnu}(\mathrm{A})$. All $\operatorname{msr}(\mathrm{A})$-positive isolates exhibited an $\mathrm{M}$ phenotype, whereas all five $\operatorname{erm}(\mathrm{C})$-positive and all three $\operatorname{Inu}(\mathrm{A})$-positive strains displayed, respectively, an inducible $\mathrm{MLS}_{\mathrm{B}}$ phenotype and an L phenotype with a positive Hodge test. Plasmid analysis indicated that $\operatorname{erm}(\mathrm{C})$ and $\ln u(\mathrm{~A})$ genes were borne by small-size plasmids (ca. $2.5 \mathrm{~kb}$ ), whereas larger plasmids (30-90 kb) harboured $\mathrm{msr}(\mathrm{A})$. In conclusion, these findings show a high prevalence of MLS resistance in S. saprophyticus, which was mainly associated with the presence of the $\operatorname{msr}(\mathrm{A})$ gene. Since $S$. saprophyticus colonises the gastrointestinal tract, it may constitute an unexpected reservoir for MLS resistance genes, in particular $\operatorname{msr}(\mathrm{A})$, among coagulase-negative staphylococci. 


\section{Introduction}

Staphylococcus saprophyticus, a member of the coagulase-negative staphylococci (CoNS), is a common cause of acute uncomplicated urinary tract infection (UTI) in young, sexually active female outpatients, accounting for up to $42 \%$ of UTIs in this population [1]. More severe complications have also been reported, including acute pyelonephritis, septicaemia, nephrolithiasis and endocarditis, as well as infections in males such as urethritis, prostatitis and nephrolithiasis [2]. Except for fosfomycin, $S$. saprophyticus is susceptible to many antimicrobial agents, including macrolidelincosamide-streptogramin (MLS) antibiotics [3-6]. However, since MLS antibiotics are excreted primarily in bile, they are not used for the treatment of UTIs. As a consequence, resistance to these antibiotics has been poorly documented in $S$. saprophyticus in comparison with other CoNS. Although S. saprophyticus appears to be an exclusive uropathogen, its major reservoir is the gastrointestinal tract, with the most common site being the rectum [7], and its mode of transmission may be through consumption of contaminated animal food products [8]. An study in the UK [9] as well as preliminary results from University Hospital of Caen (France) (unpublished data) showed a high prevalence of MLS resistance in S. saprophyticus, indicating that this species might be a potential reservoir of MLS resistance genes. However, molecular characterisation of resistance has not been yet investigated.

Although MLS antibiotics are chemically distinct, they are classified in the same group owing to their similar mechanism of action and spectrum of activity [10]. Macrolides are classified according to the number of atoms forming the lactone ring, i.e. 14-membered 
(e.g. erythromycin), 15-membered (e.g. azithromycin) or 16-membered (e.g. spiramycin). Lincomycin and clindamycin belong to the lincosamides, and streptogramins correspond to a mixture of two compounds that act synergistically, i.e. streptogramins A (e.g. dalfopristin) and streptogramins B (e.g. quinupristin). MLS antibiotics act by inhibiting protein synthesis following binding to the $50 \mathrm{~S}$ subunit (23S rRNA) of the bacterial ribosome [10].

In staphylococci, MLS resistance is mediated by three major mechanisms, namely target site modification, active efflux and drug inactivation [10]. Ribosomal alteration is mediated by a methyltransferase, encoded by erm genes (erythromycin ribosome methylase), which methylates the A2058 residue in domain $\mathrm{V}$ of the $23 \mathrm{~S}$ rRNA. Although nearly 40 erm genes have been reported so far (http://faculty.washington.edu/marilynr/), $\operatorname{erm}(\mathrm{A}), \operatorname{erm}(\mathrm{B})$ and $\operatorname{erm}(\mathrm{C})$ genes are the most frequently detected in staphylococci. This methylation results in the so-called MLS $\mathrm{B}_{\mathrm{B}}$ phenotype, which can be expressed either inducibly or constitutively. Inducible expression is characterised by unique resistance to 14- and 15-membered ring macrolides, which are inducers. Constitutive expression is characterised by resistance to all macrolides, lincosamides and streptogramins B. Mutations in 23S rRNA (A2058 and A2059) and in ribosomal proteins L4 and L22 (encoded by rp/D and rp/V genes, respectively) have been infrequently described [11-13]. Active efflux is mediated by the $m s r(\mathrm{~A})$ gene that codes for a putative efflux pump and is responsible for the so-called $\mathrm{M}$ phenotype characterised by unique resistance to 14- and 15-membered ring macrolides. The $L$ phenotype is related to acquisition of the $\ln u(A)$ gene (formerly known 
as $\operatorname{lin} A$ or $\operatorname{lin} A$ ) that encodes 3-lincomycin, 4-clindamycin O-nucleotidyltransferase, which only inactivates lincosamides.

Since molecular characterisation of MLS resistance has not been yet undertaken in $S$. saprophyticus, the aim of this study was to evaluate the prevalence of MLS resistance among a collection of $S$. saprophyticus clinical isolates recovered from a French hospital and to identify genes associated with this resistance as well as their genetic supports.

\section{Materials and methods}

\subsection{Bacterial isolates}

From 2005 to 2009, a total of 72 S. saprophyticus clinical isolates were recovered from urine specimens (pure culture $\geq 10^{5}$ colony-forming units $/ \mathrm{mL}$ ) from the University Hospital of Caen (France). Isolates were identified to species level using a VITEK 2 IDGPC card (bioMérieux, Marcy l'Etoile, France) in accordance with the manufacturer's instructions. Sequencing of the $\operatorname{sod} A$ gene was performed as described previously for 14 isolates because biochemical identification was equivocal [14].

Staphylococcus aureus ATCC 25922, S. aureus ATCC 29213 and Enterococcus faecalis ATCC 29212 were used as controls for antimicrobial susceptibility testing. Staphylococcus aureus HM290, Streptococcus pneumoniae HM28, S. aureus HM1054R, S. aureus RN4220(pUL5054) and Staphylococcus haemolyticus BM4610 
were used as $\operatorname{erm}(\mathrm{A})-, \operatorname{erm}(\mathrm{B})-, \operatorname{erm}(\mathrm{C})-, \operatorname{msr}(\mathrm{A})-$ and $\operatorname{lnu}(\mathrm{A})$-positive controls, respectively. Micrococcus luteus ATCC 9341 and streptomycin-resistant S. aureus 80CR5 were used as indicator organism for the Hodge test and as recipient in conjugation experiments, respectively.

\subsection{Antimicrobial susceptibility testing}

In vitro susceptibility was determined for all 72 isolates by disk diffusion on MuellerHinton agar (disks and medium supplied by Bio-Rad Laboratories, Marnes-la-Coquette, France) according to the guidelines of the Antibiogram Committee of the French Society for Microbiology (CA-SFM) (http://www.sfm.asso.fr). The following antibiotics were tested: cefoxitin (30 $\mu \mathrm{g})$; kanamycin $(30 \mu \mathrm{g})$; tobramycin $(10 \mu \mathrm{g})$; gentamicin $(15 \mu \mathrm{g})$; erythromycin (15 IU); lincomycin (15 $\mu \mathrm{g})$; pristinamycin (15 $\mu \mathrm{g})$; linezolid $(30 \mu \mathrm{g})$; ofloxacin $(5 \mu \mathrm{g})$; vancomycin (30 $\mu \mathrm{g})$; teicoplanin (30 $\mu \mathrm{g})$; fusidic acid $(10 \mu \mathrm{g})$; rifampicin $(30 \mu \mathrm{g})$; and trimethoprim/sulfamethoxazole (SXT) $(1.25 / 23.75 \mu \mathrm{g})$. Interpretation was performed in accordance with CA-SFM recommendations.

For MLS-resistant isolates, the minimum inhibitory concentrations (MICs) of erythromycin, spiramycin, lincomycin, clindamycin, quinupristin, dalfopristin and the combination quinupristin/dalfopristin $(\mathrm{Q} / \mathrm{D})$ were determined by the broth microdilution technique (medium supplied by Bio-Rad) according to European Committee on Antimicrobial Susceptibility Testing (EUCAST) guidelines (http://www.escmid.org/research_projects/eucast/). 
A double-disk diffusion test (D-test) was performed with erythromycin and clindamycin disks applied $20 \mathrm{~mm}$ apart (edge-to-edge). Blunting of the zone of inhibition around the clindamycin disk was considered positive for inducible $\mathrm{MLS}_{\mathrm{B}}$ resistance. The ability of the MLS-resistant strains to inactivate lincomycin and/or clindamycin was detected by the disk and radial streak test method (called the Hodge test [15]) in M. luteus ATCC 9341-seeded Mueller-Hinton agar. Distortion of the susceptibility zone of M. luteus along the line of inoculation of the test strain was considered positive, indicating antibiotic inactivation.

\subsection{Polymerase chain reaction (PCR) amplification and sequencing}

Bacterial genomic DNA was extracted using a QIAamp DNA Mini Kit (Qiagen, Courtaboeuf, France). Detection of $\operatorname{erm}(\mathrm{A}), \operatorname{erm}(\mathrm{B}), \operatorname{erm}(\mathrm{C}), \operatorname{msr}(\mathrm{A})$ and $\ln u(\mathrm{~A})$ genes was performed for MLS-resistant S. saprophyticus isolates. PCR experiments were carried out according to standard conditions using primers synthesised by Eurogentec France SAS (Angers, France) (Table 1). Briefly, $2 \mu \mathrm{L}$ of total DNA was subjected to PCR in a $50 \mu \mathrm{L}$ reaction mixture containing $1 \times \mathrm{PCR}$ buffer $[10 \mathrm{mM}$ Tris- $\mathrm{HCl}(\mathrm{pH} 8.3), 50$ $\mathrm{mM} \mathrm{KCl}$, $1.5 \mathrm{mM}$ of $\mathrm{MgCl}_{2}, 200 \mu \mathrm{M}$ of each deoxynucleotide triphosphate, $0.5 \mu \mathrm{M}$ of each primer and $1.25 \mathrm{U}$ of GoTaq ${ }^{\circledR}$ Flexi DNA Polymerase (Promega, Charbonnièresles-Bains, France). PCR amplifications were performed using a Mastercycler ${ }^{\circledR}$ gradient thermal cycler (Eppendorf, Le Pecq, France) as follows: (i) initial denaturation step of 5 min at $95^{\circ} \mathrm{C}$; (ii) 30 cycles consisting of denaturation for $30 \mathrm{~s}$ at $95^{\circ} \mathrm{C}$, annealing for 30 $\mathrm{s}$ at $50-58^{\circ} \mathrm{C}$ (Table 1) and extension for $30 \mathrm{~s}$ at $72{ }^{\circ} \mathrm{C}$; and (iii) a final extension step of $5 \min$ at $72{ }^{\circ} \mathrm{C}$. 
To detect putative mutations responsible target for site modification, a portion of the $r \mathrm{rl}$ gene for domain $\mathrm{V}$ of the $23 \mathrm{~S}$ rRNA gene as well as the entire sequence of the rp/D, $r p / V$ and $r p / C$ genes (coding for L4, L22 and L3 ribosomal proteins, respectively) were amplified by PCR using the conditions described above and specific primers (Table 1). Purified PCR products were then directly sequenced with the same sets of primers in both directions by GATC Biotech (Konstanz, Germany).

\subsection{Plasmid analysis and conjugation}

Plasmid DNA of MLS-resistant strains was prepared using a modification of the Kieser technique [19]. Lysostaphin was substituted for lysozyme and was used at a final concentration of $200 \mathrm{mg} / \mathrm{L}$. Plasmid DNA was analysed by agarose gel electrophoresis analysis, then by a Southern blot hybridisation assay with erm(C)-, $m \operatorname{sr}(\mathrm{A})-$ and $\operatorname{Inu}(\mathrm{A})-$ specific probes labelled with digoxigenin-dUTP (DIG DNA Labelling Kit; Roche, Meylan, France) according to the manufacturer's instructions. Briefly, plasmid DNA inside the gel was denatured and was then transferred onto a Hybond ${ }^{\mathrm{TM}}-\mathrm{N}+$ nylon membrane (Amersham, Courtaboeuf, France) for $2 \mathrm{~h}$ under vacuum. Following pre-hybridisation (1 h at $42{ }^{\circ} \mathrm{C}$ ), the membrane was hybridised overnight at $42^{\circ} \mathrm{C}$ and washed twice in $0.1 \%$ sodium dodecyl sulphate (SDS)-2x standard sodium citrate (SSC) for 5 min and then twice in $0.1 \%$ SDS- $0.1 \times \mathrm{SSC}$ for $15 \mathrm{~min}$ at $42{ }^{\circ} \mathrm{C}$. Hybridisation reactions were visualised colorimetrically with an NBT/BCIP Nucleic Acid Detection Kit (Roche) according to the manufacturer's instructions. 
Conjugation experiments using the streptomycin-resistant $S$. aureus $80 \mathrm{CR} 5$ strain as recipient were performed in solid culture media [20]. Transconjugants were selected on brain-heart infusion agar plates containing streptomycin (20 mg/L) and erythromycin (2 $\mathrm{mg} / \mathrm{L})$.

\section{Results}

\subsection{Antimicrobial susceptibility}

All 72 S. saprophyticus clinical isolates studied were susceptible to cefoxitin, aminoglycosides, glycopeptides, ofloxacin, linezolid, fusidic acid, rifampicin and SXT. However, 33 isolates (45.8\%) were resistant to at least one of the MLS antibiotics, comprising 29 isolates (40.3\%) resistant to erythromycin only, 3 isolates $(4.2 \%)$ resistant to both erythromycin and lincomycin and 1 isolate $(1.4 \%)$ resistant to lincomycin only. No resistance to pristinamycin or $Q / D$ was observed.

For the 33 MLS-resistant strains, MIC ranges were as follows: erythromycin, $0.12 \mathrm{mg} / \mathrm{L}$ to $>256 \mathrm{mg} / \mathrm{L}$; spiramycin, $0.5-128 \mathrm{mg} / \mathrm{L}$; lincomycin, $0.12 \mathrm{mg} / \mathrm{L}$ to $>256 \mathrm{mg} / \mathrm{L}$; clindamycin, $0.03 \mathrm{mg} / \mathrm{L}$ to $>256 \mathrm{mg} / \mathrm{L}$; dalfopristin, $0.12-16 \mathrm{mg} / \mathrm{L}$; quinupristin, $1-8$ $\mathrm{mg} / \mathrm{L}$; and Q/D, $0.12-0.5 \mathrm{mg} / \mathrm{L}$ (Table 2). The MICs for $50 \%$ and $90 \%$ of the organisms $\left(\mathrm{MIC}_{50}\right.$ and $\mathrm{MIC}_{90}$ values) were, respectively: erythromycin, $32 \mathrm{mg} / \mathrm{L}$ and $>256 \mathrm{mg} / \mathrm{L}$; spiramycin, $4 \mathrm{mg} / \mathrm{L}$ and $8 \mathrm{mg} / \mathrm{L}$; lincomycin, $0.25 \mathrm{mg} / \mathrm{L}$ and $8 \mathrm{mg} / \mathrm{L}$; clindamycin, 0.03 $\mathrm{mg} / \mathrm{L}$ and $0.06 \mathrm{mg} / \mathrm{L}$; dalfopristin, $2 \mathrm{mg} / \mathrm{L}$ and $4 \mathrm{mg} / \mathrm{L}$; quinupristin, $4 \mathrm{mg} / \mathrm{L}$ and $8 \mathrm{mg} / \mathrm{L}$; and $\mathrm{Q} / \mathrm{D}, 0.25 \mathrm{mg} / \mathrm{L}$ and $0.5 \mathrm{mg} / \mathrm{L}$. 


\section{2. $M L S$ resistance phenotypes}

Four phenotypes were observed among the $33 \mathrm{MLS}$-resistant isolates. A large majority of them (24 isolates; $72.7 \%$ ) displayed an M phenotype, whilst 5 isolates (15.2\%) exhibited inducible $\mathrm{MLS}_{\mathrm{B}}$ resistance (Table 2). Three isolates $(9.1 \%)$ displayed an $\mathrm{ML}$ phenotype with low quinupristin MICs, which is not consistent with constitutive $\mathrm{MLS}_{B}$ resistance and would probably result from a combination of $M$ and $L$ phenotypes. $A$ single isolate (3.0\%) had an $L$ phenotype (Table 2). Only three isolates presented a positive Hodge test; strain no. 15 was negative for this test.

\subsection{Characterisation of MLS resistance genes}

The most prevalent resistance determinant was $\operatorname{msr}(\mathrm{A})$, which was detected alone in 24 strains $(72.7 \%)$, followed by erm $(\mathrm{C})$ and $\ln u(\mathrm{~A})$ detected alone in 5 strains $(15.2 \%)$ and 1 strain (3.0\%), respectively (Table 2). Two strains (6.1\%) were positive for both $m s r(\mathrm{~A})$ and $\ln u(A)$ genes, whereas a single strain (strain no. 15) was negative for all screened genes. No $\operatorname{erm}(\mathrm{A})$ and $\operatorname{erm}(\mathrm{B})$ genes were detected. All isolates harbouring the $\operatorname{msr}(\mathrm{A})$ gene alone exhibited an M phenotype with a moderate level of resistance to erythromycin (MIC $=4-128 \mathrm{mg} / \mathrm{L}$ ) and susceptibility to other MLS antibiotics (Table 2). All five erm(C)-positive strains presented an inducible $\mathrm{MLS}_{\mathrm{B}}$ phenotype, with high-level resistance to erythromycin (MIC $>256 \mathrm{mg} / \mathrm{L}$ ) in four of them as well as susceptibility to other MLS antibiotics for all five (Table 2). Finally, the three $\operatorname{lnu}(\mathrm{A})$-positive strains were 
resistant to lincomycin (MIC $=8-128 \mathrm{mg} / \mathrm{L})$ but remained susceptible to clindamycin $(\mathrm{MIC}=0.03-0.12 \mathrm{mg} / \mathrm{L})$.

Isolate no. 15 , which was negative for all five resistance genes, displayed a combined $M L$ phenotype with resistance to erythromycin $(\mathrm{MIC}=16 \mathrm{mg} / \mathrm{L})$, spiramycin $(\mathrm{MIC}=128$ $\mathrm{mg} / \mathrm{L}$ ) and lincosamides (MIC $>256 \mathrm{mg} / \mathrm{L}$ ), but susceptibility to streptogramins A and B. Since this phenotype did not correspond to any known resistance gene(s), the presence of chromosomal mutations in domestic genes was evaluated. No mutation was detected in $r r l, r p / D$ and $r p / V$ genes, whereas a unique mutation (A103G) leading to an isofunctional substitution (I35V) was found in the $r p / C$ gene. Therefore, the mechanism of MLS resistance in this isolate remains unknown.

\subsection{Genetic support of MLS resistance genes}

All 33 MLS-resistant S. saprophyticus strains contained at least one plasmid [Fig. 1(A1),(A2)]. Southern blot experiments showed that all detected resistance genes were located on plasmids. The size of $\operatorname{msr}(\mathrm{A})$-containing plasmids varied from $\mathrm{ca}$. $30 \mathrm{~kb}$ to 90 kb [Fig. 1(A1),(A2)], whereas that of $\operatorname{erm}(\mathrm{C})$ - and $\operatorname{lnu}(\mathrm{A})$-containing plasmids was much smaller, ca. $2.5 \mathrm{~kb}$ [Fig. 1(B),(C)].

Since erm(C)- and $\ln u(\mathrm{~A})$-containing plasmids were, in theory, too small to be selftransferable or mobilisable, conjugation experiments were carried out only with several isolates carrying $m s r(\mathrm{~A})$-containing plasmids. Unfortunately, it was not possible to transfer the $m s r(A)$ gene from five different strains, for which different sizes of plasmids 
were observed (strains no. 4, 7, 17, 18 and 26), to S. aureus 80CR5 recipient despite repeated attempts.

\section{Discussion}

In this study, S. saprophyticus clinical isolates were susceptible to almost all antimicrobial agents. These findings are in agreement with previously reported data where the prevalence of acquired resistance is generally $<5 \%[3-6,9,21,22]$, confirming that $S$. saprophyticus is a multisusceptible species. Although all of the studied strains were susceptible to cefoxitin, meticillin resistance by acquisition of the mecA gene has been rarely reported $[23,24]$.

Surprisingly, the prevalence of MLS resistance, particularly to erythromycin, is much higher than previously reported. According to studies conducted in the early 1980 s, the prevalence of resistance to erythromycin and clindamycin varied from $8 \%$ to $16 \%$ and $0 \%$ to $6 \%$, respectively [3-6]. Only a single study conducted in the UK in the late 1990 s reported a higher prevalence $(25.1 \%)$ of resistance to erythromycin, whilst the prevalence of resistance to clindamycin was only $1.5 \%$ [9]. A more recent study on antimicrobial susceptibility of $S$. saprophyticus clinical isolates recovered in Japan in 2003 showed that only 10 isolates $(9.9 \%)$ were highly resistant to erythromycin (MIC $\geq$ $64 \mathrm{mg} / \mathrm{L}$ ) [23]. The high incidence of MLS resistance in the collection of isolates studied here might be the reflection of a particular situation in our hospital or a global evolution towards increased resistance. Finally, no $S$. saprophyticus resistant to the combination 
of streptogramins A and B was found in this study; this resistance has not been yet reported in this species.

No data are available regarding the distribution of MLS resistance genes in $S$. saprophyticus. This study showed that the distribution of these genes is different from that generally reported for CoNS, mostly Staphylococcus epidermidis, S. haemolyticus and Staphylococcus hominis [17,25-27]. In these species, the most prevalent gene is generally $\operatorname{erm}(\mathrm{C})$ with a prevalence ranging from $44 \%$ to $78 \%$, followed by the $\operatorname{erm}(\mathrm{A})$ gene with a prevalence ranging from $5 \%$ to $32 \%$. Efflux of macrolides due to $\operatorname{msr}(\mathrm{A})$ is a mechanism found in only a minority of CoNS, representing $11-24 \%$ of erythromycin resistance [17,25-27]. In contrast, in this study MLS resistance in S. saprophyticus was mainly due to the presence of the $\operatorname{msr}(\mathrm{A})$ gene, as previously described in $S$. haemolyticus [28]. The erm(B) gene was not detected in this study, however this is not surprising since this resistance gene has been seldom described in staphylococci previously. Little is known about the prevalence of the $\operatorname{Inu}(\mathrm{A})$ gene in CoNS. A study reporting a prevalence of $5 \%$ identified a frequent association with $\operatorname{msr}(\mathrm{A})$ or an erm gene [17]. Note that a single study contrasts with data from other studies, reporting a high occurrence of $\operatorname{msr}(\mathrm{A})(53 \%)$ and $\operatorname{Inu}(\mathrm{A})(30 \%)$ genes among a collection of 98 CoNS comprising mostly S. haemolyticus $(n=62)$ and S. epidermidis $(n=27)$ [29].

The genetic support of MLS resistance in S. saprophyticus has been poorly studied. The current findings are similar to those previously reported for $S$. aureus and CoNS. erm(C) genes are usually located on small, structurally related, multicopy plasmids 
ranging in size between $2.3 \mathrm{~kb}$ and $2.5 \mathrm{~kb}$, and more rarely on structurally diverse larger plasmids of 3.7-4 kb [30]. To date, only one erm(C)-carrying plasmid of $4 \mathrm{~kb}$ has been characterised from S. saprophyticus [31]. Inu(A) genes are also located on small, structurally different plasmids of $2.3-3.8 \mathrm{~kb}[32,33]$, whereas the $\operatorname{msr}(\mathrm{A})$ gene was located on larger plasmids of ca. $20-40 \mathrm{~kb}[30,34]$. Results of conjugation experiments suggest that these $\operatorname{msr}(\mathrm{A})$-containing plasmids do not encode their own transfer function. However, they might be mobilised by other mobile elements, which remain to be evidenced. Finally, exchange of $\operatorname{erm}(\mathrm{C})$ - and $\operatorname{lnu}(\mathrm{A})$-containing plasmids might be due to generalised transduction mediated by many bacteriophages known to be present in staphylococci [35].

For S. saprophyticus strain no. 15 , only a single point mutation has been identified in the $r p / C$ gene coding for the L3 ribosomal protein. Various mutations in this gene have been only associated with resistance to oxazolidinones [36,37] and pleuromutilins [38], but at different positions. However, strain no. 15 was entirely susceptible to linezolid (an oxazolidinone) and tiamulin (a pleuromutilin) (data not shown). The involvement of this mutation in putative MLS resistance should be confirmed by site-directed mutagenesis. In addition, this strain harboured at least two plasmids (sizes ca. $60 \mathrm{~kb}$ and $80 \mathrm{~kb}$ ) [Fig. $1(A 1)]$ and further investigations regarding the transferability of the resistance are in progress in addition to cloning experiments.

This is the first description of the distribution of MLS resistance genes in $S$. saprophyticus showing that, in contrast to other CoNS, MLS resistance in $S$. 
saprophyticus is mainly due to the presence of the plasmid-mediated $m s r(\mathrm{~A})$ gene and that this species may be a reservoir of these resistance genes among staphylococci.

\section{Funding}

This work was funded by a grant from the Ministère de l'Éducation nationale et de la recherche (UPRES-EA2128), Université Caen Basse-Normandie, France.

\section{Competing interests}

None declared.

\section{Ethical approval}

Not required. 


\section{References}

[1] von Eiff C, Peters G, Heilmann C. Pathogenesis of infections due to coagulasenegative staphylococci. Lancet Infect Dis 2002;2:677-85.

[2] Raz R, Colodner R, Kunin CM. Who are you-Staphylococcus saprophyticus? Clin Infect Dis 2005;40:896-8.

[3] Price SB, Flournoy DJ. Comparison of antimicrobial susceptibility patterns among coagulase-negative staphylococci. Antimicrob Agents Chemother 1982;21:436-40.

[4] Marrie TJ, Kwan C. Antimicrobial susceptibility of Staphylococcus saprophyticus and urethral staphylococci. Antimicrob Agents Chemother 1982;22:395-7.

[5] Nicolle LE, Harding GK. Susceptibility of clinical isolates of Staphylococcus saprophyticus to fifteen commonly used antimicrobial agents. Antimicrob Agents Chemother 1982;22:895-6.

[6] Fass RJ, Helsel VL, Barnishan J, Ayers LW. In vitro susceptibilities of four species of coagulase-negative staphylococci. Antimicrob Agents Chemother 1986;30:545-52.

[7] Hedman P, Ringertz O, Olsson K, Wollin R. Plasmid-identified Staphylococcus saprophyticus isolated from the rectum of patients with urinary tract infections. Scand J Infect Dis 1991;23:569-72.

[8] Hedman P, Ringertz O, Eriksson B, Kvarnfors P, Andersson M, Bengtsson L, et al. Staphylococcus saprophyticus found to be a common contaminant of food. J Infect 1990;21:11-9.

[9] Andrews J, Ashby J, Jevons G, Marshall T, Lines N, Wise R. A comparison of antimicrobial resistance rates in Gram-positive pathogens isolated in the UK from 
October 1996 to January 1997 and October 1997 to January 1998. J Antimicrob Chemother 2000;45:285-93.

[10] Leclercq R. Mechanisms of resistance to macrolides and lincosamides: nature of the resistance elements and their clinical implications. Clin Infect Dis 2002;34:48292.

[11] Prunier AL, Malbruny B, Tande D, Picard B, Leclercq R. Clinical isolates of Staphylococcus aureus with ribosomal mutations conferring resistance to macrolides. Antimicrob Agents Chemother 2002;46:3054-6.

[12] Prunier AL, Malbruny B, Laurans M, Brouard J, Duhamel JF, Leclercq R. High rate of macrolides resistance in Staphylococcus aureus strains from patients with cystic fibrosis reveals high proportions of hypermutable strains. J Infect Dis 2003;187:1709-16.

[13] Prunier AL, Trong HN, Tande D, Segond C, Leclercq R. Mutation of L4 ribosomal protein conferring unusual macrolide resistance in two independent clinical isolates of Staphylococcus aureus. Microb Drug Resist 2005;11:18-20.

[14] Poyart C, Quesne G, Boumaila C, Trieu-Cuot P. Rapid and accurate specieslevel identification of coagulase-negative staphylococci by using the $\operatorname{sod} A$ gene as a target. J Clin Microbiol 2001;39:4296-301.

[15] Hodge W, Ciak J, Tramont EC. Simple method for detection of penicillinaseproducing Neisseria gonorrhoeae. J Clin Microbiol 1978;7:102-3.

[16] Phuc Nguyen MC, Woerther PL, Bouvet M, Andremont A, Leclercq R, Canu A. Escherichia coli as reservoir for macrolide resistance genes. Emerg Infect Dis $2009 ; 15: 1648-50$. 
[17] Lina G, Quaglia A, Reverdy ME, Leclercq R, Vandenesch F, Etienne J. Distribution of genes encoding resistance to macrolides, lincosamides, and streptogramins among staphylococci. Antimicrob Agents Chemother 1999;43:10626.

[18] Bingen E, Leclercq R, Fitoussi F, Brahimi N, Malbruny B, Deforche D, et al. Emergence of group A Streptococcus strains with different mechanisms of macrolide resistance. Antimicrob Agents Chemother 2002;46:1199-203.

[19] Kieser T. Factors affecting the isolation of CCC DNA from Streptomyces lividans and Escherichia coli. Plasmid 1984;12:19-36.

[20] Engel HW, Soedirman N, Rost JA, van Leeuwen WJ, van Embden JD.

Transferability of macrolide, lincomycin, and streptogramin resistances between groups A, B, and D streptococci, Streptococcus pneumoniae, and Staphylococcus aureus. J Bacteriol 1980;142:407-13.

[21] Gupta K, Hooton TM, Wobbe CL, Stamm WE. The prevalence of antimicrobial resistance among uropathogens causing acute uncomplicated cystitis in young women. Int J Antimicrob Agents 1999;11:305-8.

[22] Kahlmeter G. An international survey of the antimicrobial susceptibility of pathogens from uncomplicated urinary tract infections: the ECO.SENS Project. $\mathrm{J}$ Antimicrob Chemother 2003;51:69-76.

[23] Higashide M, Kuroda M, Omura CT, Kumano M, Ohkawa S, Ichimura S, et al. Methicillin-resistant Staphylococcus saprophyticus isolates carrying staphylococcal cassette chromosome mec have emerged in urogenital tract infections. Antimicrob Agents Chemother 2008;52:2061-8. 
[24] Fessler AT, Billerbeck C, Kadlec K, Schwarz S. Identification and characterization of methicillin-resistant coagulase-negative staphylococci from bovine mastitis. J Antimicrob Chemother 2010;65:1576-82.

[25] Bouchami O, Achour W, Ben Hassen A. Prevalence and mechanisms of macrolide resistance among Staphylococcus epidermidis isolates from neutropenic patients in Tunisia. Clin Microbiol Infect 2007;13:103-6.

[26] Aktas Z, Aridogan A, Kayacan CB, Aydin D. Resistance to macrolide, lincosamide and streptogramin antibiotics in staphylococci isolated in Istanbul, Turkey. J Microbiol 2007;45:286-90.

[27] Gatermann SG, Koschinski T, Friedrich S. Distribution and expression of macrolide resistance genes in coagulase-negative staphylococci. Clin Microbiol Infect 2007;13:777-81.

[28] Gherardi G, De Florio L, Lorino G, Fico L, Dicuonzo G. Macrolide resistance genotypes and phenotypes among erythromycin-resistant clinical isolates of Staphylococcus aureus and coagulase-negative staphylococci, Italy. FEMS Immunol Med Microbiol 2009;55:62-7.

[29] Novotna G, Adamkova V, Janata J, Melter O, Spizek J. Prevalence of resistance mechanisms against macrolides and lincosamides in methicillin-resistant coagulasenegative staphylococci in the Czech Republic and occurrence of an undefined mechanism of resistance to lincosamides. Antimicrob Agents Chemother 2005;49:3586-9.

[30] Luthje P, Schwarz S. Antimicrobial resistance of coagulase-negative staphylococci from bovine subclinical mastitis with particular reference to macrolide- 
lincosamide resistance phenotypes and genotypes. J Antimicrob Chemother 2006;57:966-9.

[31] Hauschild T, Luthje P, Schwarz S. Characterization of a novel type of $M_{L} S_{B}$ resistance plasmid from Staphylococcus saprophyticus carrying a constitutively expressed erm(C) gene. Vet Microbiol 2006;115:258-63.

[32] Leclercq R, Carlier C, Duval J, Courvalin P. Plasmid-mediated resistance to lincomycin by inactivation in Staphylococcus haemolyticus. Antimicrob Agents Chemother 1985;28:421-4.

[33] Luthje P, von Kockritz-Blickwede M, Schwarz S. Identification and characterization of nine novel types of small staphylococcal plasmids carrying the lincosamide nucleotidyltransferase gene Inu(A). J Antimicrob Chemother 2007;59:600-6.

[34] Ross JI, Farrell AM, Eady EA, Cove JH, Cunliffe WJ. Characterisation and molecular cloning of the novel macrolide-streptogramin B resistance determinant from Staphylococcus epidermidis. J Antimicrob Chemother 1989;24:851-62.

[35] Novick RP. Staphylococcal plasmids and their replication. Annu Rev Microbiol 1989;43:537-65.

[36] Locke JB, Hilgers M, Shaw KJ. Novel ribosomal mutations in Staphylococcus aureus strains identified through selection with the oxazolidinones linezolid and torezolid (TR-700). Antimicrob Agents Chemother 2009;53:5265-74.

[37] Locke JB, Hilgers M, Shaw KJ. Mutations in ribosomal protein L3 are associated with oxazolidinone resistance in staphylococci of clinical origin. Antimicrob Agents Chemother 2009;53:5275-8. 
[38] Long KS, Poehlsgaard J, Hansen LH, Hobbie SN, Bottger EC, Vester B. Single $23 S$ rRNA mutations at the ribosomal peptidyl transferase centre confer resistance to valnemulin and other antibiotics in Mycobacterium smegmatis by perturbation of the drug binding pocket. Mol Microbiol 2009;71:1218-27. 
Fig. 1. Plasmid content analysis of Staphylococcus saprophyticus isolates. Ethidium bromide-stained electrophoresis pattern of undigested plasmids (left) and corresponding Southern hybridisation assay (right) using a specific probe for (A1/A2) $m s r(A),(B)$ erm(C) or (C) Inu(A). Lanes 1-33, refer to strains described in Table 2; M, Escherichia coli NCTC 50192 (used as reference for plasmid sizes). 


\section{Table 1}

Oligonucleotide primers used in this study

\begin{tabular}{|c|c|c|c|c|c|}
\hline $\begin{array}{l}\text { Target } \\
\text { gene }\end{array}$ & Primer $^{\mathrm{a}}$ & Sequence $\left(5^{\prime} \rightarrow 3^{\prime}\right)$ & $\begin{array}{l}\text { Amplicon size } \\
\text { (bp) }\end{array}$ & $\begin{array}{l}\text { Annealing } \\
\text { temperature }\left({ }^{\circ} \mathrm{C}\right)\end{array}$ & Source \\
\hline \multirow[t]{2}{*}{$\operatorname{erm}(\mathrm{A})$} & ermA-F & TCTAAAAAGCATGTAAAAGAAA & 533 & 52 & [16] \\
\hline & ermA-R & CGATACTTTTTGTAGTCCTTC & & & \\
\hline \multirow[t]{2}{*}{$\operatorname{erm}(\mathrm{B})$} & ermB-F & CCGTTTACGAAATTGGAACAGGTAAAGGGC & 359 & 55 & [17] \\
\hline & ermB-R & GAATCGAGACTTGAGTGTGC & & & \\
\hline \multirow[t]{2}{*}{$\operatorname{erm}(\mathrm{C})$} & ermC-F & GCTAATATTGTTTAAATCGTCAATTCC & 572 & 52 & [17] \\
\hline & ermC-R & GGATCAGGAAAAGGACATTTTAC & & & \\
\hline \multirow[t]{2}{*}{$\operatorname{msr}(\mathrm{A})$} & msrA-F & TGCTGACACAATTTGGGAT & 278 & 54 & This \\
\hline & msrA-R & GAGCAGCCTTCTCAACC & & & study \\
\hline \multirow[t]{2}{*}{$\ln u(A)$} & $\operatorname{lin} A-F$ & GGTGGCTGGGGGGTAGATGTATTAACTGG & 323 & 57 & [17] \\
\hline & $\operatorname{lin} A-R$ & GCTTCTTTTGAAATACATGGTATTTTTCGA & & & \\
\hline \multirow[t]{2}{*}{$r r l$} & 23SCPU8 & GACCCGCACGAAAGGCG & 942 & 50 & [18] \\
\hline & 23SCPL10 & ATAAGTCCTCGAGCGATTAG & & & \\
\hline \multirow[t]{2}{*}{$r p / D$} & L4F & GACGTATGGGCGGTAACAC & 1007 & 52 & This \\
\hline & L4R & CCTTGGTAACGGCCCATAC & & & study \\
\hline \multirow[t]{2}{*}{$r p / V$} & L22F & CGTAACAGAAGATATGGTTG & 636 & 52 & This \\
\hline & L22R & CGTAACAGAAGATATGGTTG & & & study \\
\hline
\end{tabular}




\begin{tabular}{|c|c|c|c|c|}
\hline \multirow[t]{2}{*}{$r p /$} & L3F & ACTGTTATTCGTGCCGTGC & $936 \quad 58$ & This \\
\hline & L3R & CGCTTAGTTCAACTGAACCT & & study \\
\hline
\end{tabular}

${ }^{a} F$, sense primer; $R$, antisense primer. 


\section{Table 2}

Susceptibility profiles to macrolide-lincosamide-streptogramin (MLS) antibiotics and corresponding resistance genotypes of 33 MLS-resistant Staphylococcus saprophyticus clinical isolates

\begin{tabular}{|c|c|c|c|c|c|c|c|c|c|c|c|c|c|c|}
\hline \multirow[t]{2}{*}{ Strain } & \multicolumn{7}{|c|}{$\mathrm{MIC}(\mathrm{mg} / \mathrm{L})$} & \multirow[t]{2}{*}{ D-test } & \multirow[t]{2}{*}{ Hodge test } & \multicolumn{5}{|c|}{ PCR detection of: } \\
\hline & $\begin{array}{l}\text { ERY } \\
\end{array}$ & SPI & LIN & CLI & DAL & QUI & $\mathrm{Q} / \mathrm{D}$ & & & $\overline{e r m}(\mathrm{~A})$ & erm(B) & erm(C) & $m s r(\mathrm{~A})$ & $\ln u(\mathrm{~A})$ \\
\hline 1 & 64 & 4 & 0.12 & 0.03 & 4 & 4 & 0.25 & - & - & - & - & - & + & - \\
\hline 2 & 64 & 4 & 0.12 & 0.03 & 4 & 4 & 0.25 & - & - & - & - & - & + & - \\
\hline 3 & 64 & 8 & 0.5 & 0.06 & 4 & 2 & 0.25 & - & - & - & - & - & + & - \\
\hline 4 & 64 & 4 & 0.5 & 0.06 & 2 & 4 & 0.12 & - & - & - & - & - & + & - \\
\hline 5 & 16 & 4 & 0.12 & 0.03 & 4 & 4 & 0.25 & - & - & - & - & - & + & - \\
\hline 6 & 32 & 1 & 0.12 & 0.03 & 4 & 4 & 0.25 & - & - & - & - & - & + & - \\
\hline 7 & 128 & 8 & 0.5 & 0.06 & 4 & 8 & 0.5 & - & - & - & - & - & + & - \\
\hline 8 & $>256$ & 4 & 0.5 & 0.06 & 2 & 8 & 0.25 & + & - & - & - & + & - & - \\
\hline 9 & 8 & 1 & 0.12 & 0.03 & 0.5 & 1 & 0.12 & + & - & - & - & + & - & - \\
\hline 10 & 32 & 2 & 0.25 & 0.03 & 2 & 4 & 0.25 & - & - & - & - & - & + & - \\
\hline 11 & 4 & 2 & 64 & 0.06 & 4 & 2 & 0.25 & - & + & - & - & - & + & + \\
\hline 12 & 16 & 4 & 0.25 & 0.03 & 2 & 4 & 0.25 & - & - & - & - & - & + & - \\
\hline 13 & 128 & 8 & 0.12 & 0.06 & 4 & 8 & 0.5 & - & - & - & - & - & + & - \\
\hline 14 & 128 & 4 & 0.12 & 0.03 & 4 & 8 & 0.5 & - & - & - & - & - & + & - \\
\hline 15 & 16 & 128 & $>256$ & $>256$ & 1 & 8 & 0.25 & - & - & - & - & - & - & - \\
\hline 16 & 16 & 2 & 0.12 & 0.03 & 1 & 4 & 0.25 & - & - & - & - & - & + & - \\
\hline
\end{tabular}




\begin{tabular}{llllllllllllllll}
\hline 17 & 8 & 4 & 0.5 & 0.03 & 2 & 4 & 0.25 & - & - & - & - & - & + & - \\
18 & 16 & 1 & 0.12 & 0.03 & 4 & 4 & 0.25 & - & - & - & - & - & + & - \\
19 & 32 & 1 & 0.12 & 0.03 & 0.5 & 8 & 0.25 & - & - & - & - & - & + & - \\
20 & 16 & 2 & 0.5 & 0.03 & 2 & 8 & 0.25 & - & - & - & - & - & + & - \\
21 & 16 & 4 & 0.5 & 0.03 & 1 & 8 & 0.25 & - & - & - & - & - & + & - \\
22 & 0.12 & 1 & 8 & 0.03 & 1 & 2 & 0.25 & - & + & - & - & - & - & + \\
23 & $>256$ & 2 & 0.5 & 0.03 & 2 & 4 & 0.25 & + & - & - & - & + & - & - \\
24 & $>256$ & 4 & 0.25 & 0.03 & 4 & 2 & 0.25 & + & - & - & - & + & - & - \\
25 & $>256$ & 4 & 0.5 & 0.12 & 2 & 4 & 0.25 & + & - & - & - & + & - & - \\
26 & 128 & 16 & 0.5 & 0.06 & 16 & 8 & 0.5 & - & - & - & - & - & + & - \\
27 & 128 & 2 & 0.5 & 0.03 & 2 & 8 & 0.25 & - & - & - & - & - & + & - \\
28 & 64 & 8 & 128 & 0.12 & 16 & 8 & 0.5 & - & + & - & - & - & + & + \\
29 & 64 & 8 & 0.25 & 0.03 & 2 & 8 & 0.5 & - & - & - & - & - & + & - \\
30 & 8 & 2 & 0.25 & 0.03 & 2 & 4 & 0.25 & - & - & - & - & - & + & - \\
31 & 16 & 0.5 & 0.12 & 0.03 & 0.12 & 1 & 0.12 & - & - & - & - & - & + & - \\
32 & 128 & 8 & 0.25 & 0.03 & 4 & 8 & 0.25 & - & - & - & - & - & + & - \\
33 & 8 & 2 & 0.25 & 0.03 & 4 & 8 & 0.25 & - & - & - & - & - & + & - \\
\hline MIC, minimum inhibitory concentration; ERY, erythromycin; SPI, spiramycin; LIN, lincomycin; CLI, clindamycin; DAL,
\end{tabular}



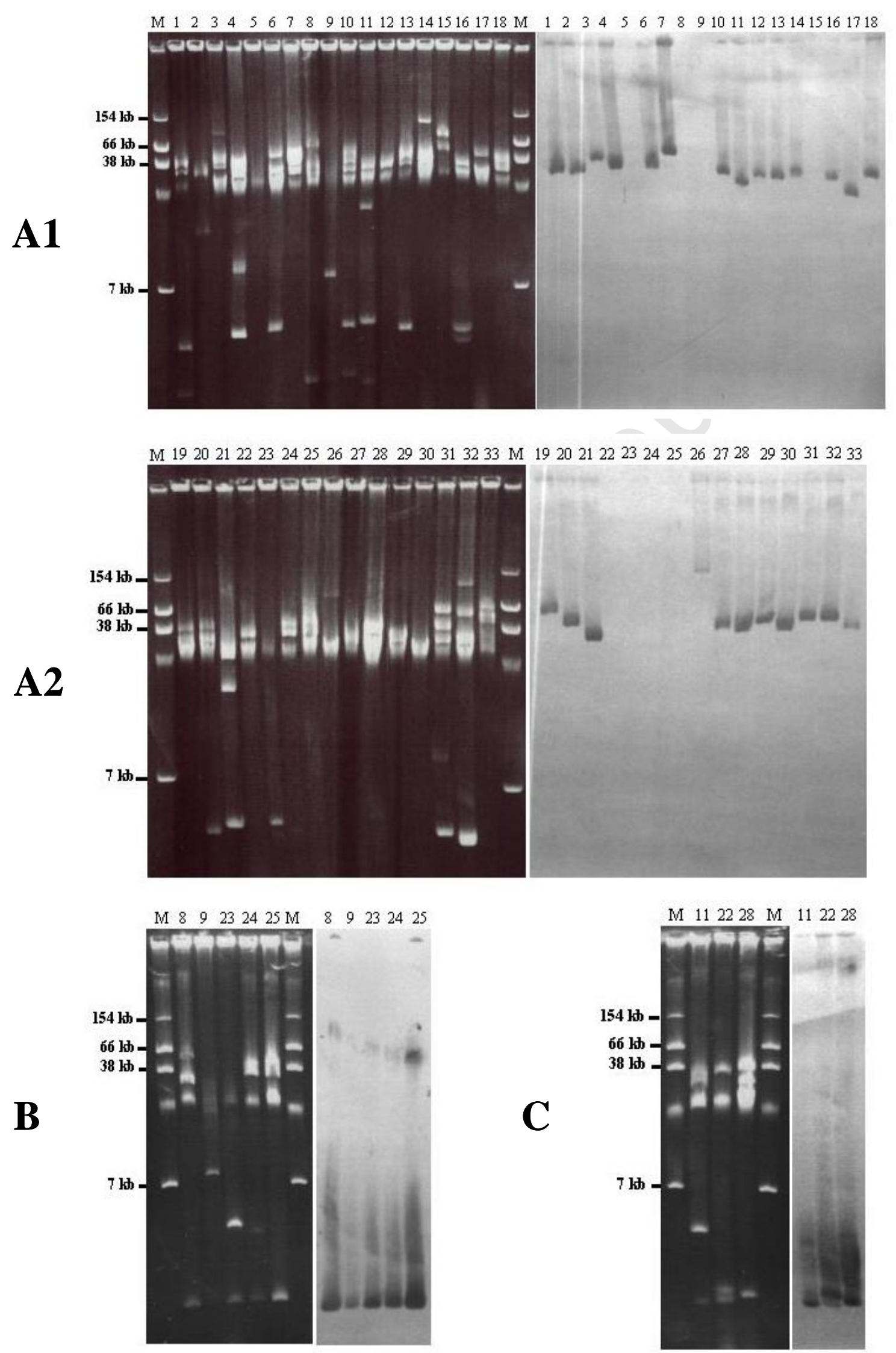